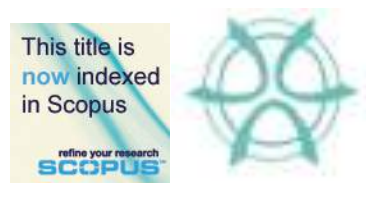

PLANNING MALAYSIA:

Journal of the Malaysian Institute of Planners

SPECIAL ISSUE IV (2016), Page 209 - 224

\title{
ISLAMISATION OF TOWN PLANNING EDUCATION: A REVIEW ON THE COURSES OFFERED BY THE DEPARTMENT OF URBAN AND REGIONAL PLANNING, INTERNATIONAL ISLAMIC UNIVERSITY MALAYSIA
}

\author{
Azila Ahmad Sarkawi ${ }^{1}$, Alias Abdullah ${ }^{2} \&$ NorimahMd Dali $^{3}$ \\ 1,2,3 Kulliyyah of Architecture \& Environmental Design \\ INTERNATIONAL ISLAMIC UNIVERSITY MALAYSIA
}

\begin{abstract}
The Islamisation of the town planning education in Malaysia especially in the Department of Urban and Regional Planning, Kulliyyah of Architecture and Environmental Design, International Islamic University Malaysia (IIUM) could successfully be materialized via the smart team-teaching approach where lecturers from the town planning Department collaborate with their counterpart in the Islamic studies Kulliyyah. This paper reports a desk study on the status of Islamic inputs in the current town planning course content. Out of 140 credit hours of town planning core courses and University required courses, it was found that $34 \%$ have already embodied Islamic-related topics whilst the remaining $66 \%$ were silent. Enhancements via compatible Islamic inputs to strengthen the existing curricula need to be done for the former while for the latter new Islamic inputs need to be incorporated. This paper reiterates that the epistemological and methodological approach combined is the way forward for sustainable education.
\end{abstract}

Keyword: Islamisation, town planning, epistemological, sustainable education

\section{INTRODUCTION}

Town Planning education aims at preparing a group of professionals who are able to manifest the sphere of town planning widely accepted as "the art and science of ordering the use of land and the character and siting of building and communication routes so as to secure the maximum degree of economy, convenience and beauty" (Keeble, 1969). Delving into this definition, town planning revolves around questions of accessibility, deployment of resources, land use configuration and visual pleasantness. To attain this aim, planning curriculum has been designed in such a way as to equip students with knowledge on physical planning, management, built environment, technology and professional conducts. The nature and scope of planning continues to be contentious due to its multidimensional and dynamic nature. Thus, in some circumstances, planners often find themselves caught between flexibility and rigidity of town planning guidelines and plans. 
Azila Ahmad Sarkawi, Alias Abdullah \& Norimah Md Dali

Islamisation of Town Planning Education: A Review on the Courses Offered by the Department of Urban and Regional Planning, International Islamic University Malaysia

Given this dynamic situation, the need for training, skill upgrading and knowledge enhancement in the field of planning is demanding. This is to ensure the meaning behind the slogan 'planning for the people, by the people and with the people' is achievable, or in the Islamic context, it is a manifestation of the human role as a khalifah (vicegerent) on earth. However, planning is not alone as far as the built environment is concern. Admittedly, planning is a body of knowledge related to the built and natural environments apart from architecture, land and property management, engineering, quantity surveying, construction technology and landscape design. In this regard, the built environment is a result of humanly made and minds for human comfort and well-being shaped by the context (Bartuska, n.d., p.5).

On the one hand, the built environment body of knowledge appears to have been able to serve its purpose in terms of efforts in ensuring and maintaining Earth's resources so that it remained in its present form. But on the other hand, the frequent occurrences of floods, pollution, de-forestation, droughts, etc. suggest that man has failed to carry the amanah (trusts) as the Earth's khalifah (custodian). To this end, among the question that could be asked is whether man possesses the appropriate knowledge to manage the Earth? In seeking answers to this question, a study focusing on knowledge areas related to the built environment was carried out. In this study, the programme structure and course outlines for the Bachelor in Urban and Regional Planning (BURP) offered by the Kulliyyah of Architecture and Environmental Design, IIUM was chosen as a model to represent the knowledge areas for the built environment. Imbuing with the Islamic paradigm of planning, this paper discusses the Islamic input embedded in the course contents of the BURP in IIUM. This paper is structured under four parts namely an introduction, an overview of the BURP programme, a study on the planning course contents, and a conclusion.

\section{An Overview of the BURP programme at KAED, IIUM}

In IIUM, BURP is a degree programme offered under the Department of Urban and Regional Planning, Kulliyyah of Architecture and Environmental Design. It is a fouryear degree programme for those who have successfully completed their matriculation programme for the SPM (Malaysian Education Certificate) or GCE 'O' level holder and pre-sessional programme for STPM (Malaysian Higher Education Certificate) or GCE 'A' level holder. Other avenues to the BURP programme in IIUM are Diploma in Architecture, Landscape, Land Survey or other built environment-related field and Diploma of Urban and Regional Planning where the holders will enroll into year 2 and year 3 of the programme respectively. Since its inception in 1996, the programme has produced 368 graduates local and international.

Together with the other twelve Kulliyyahs in IIUM, BURP in KAED is translating the IIUM's vision and mission of becoming a leading international centre of educational excellence which seeks to restore the dynamic and progressive role of the Muslim Ummah in all branches of knowledge and intellectual discourse, thereby actualizing the mission of Integration, Islamisation, Internationalization, and Comprehensive Excellence in every aspect. IIUM was officially established on $20^{\text {th }}$ May, 1983 when the University received its 'Establishment Order' from His Majesty the Yang di-Pertuan Agong, HRH Sultan Haji Ahmad Shah Al-Musta'in Billah ibni Al-Marhum Sultan Abu Bakar Ri'ayatuddin Al- 
Mu'adzam Shah after an exchange of Diplomatic Notes of co-sponsorship between the Government of Malaysia (host country) and a number of Muslim Governments, namely Bangladesh, Egypt, Libya, Maldives, Pakistan, Saudi Arabia, Turkey and the Organisation of Islamic Countries (OIC). IIUM is the only public university in Malaysia which uses English as its medium of instruction in its everyday operations. In addition, Arabic is used as the medium of instruction for undergraduate and postgraduate programmes in the Kulliyyah of Islamic Revealed Knowledge and Human Sciences. By year 2020, IIUM is strategically planning to be a Premier Global Islamic University upholding the six trusts as shown in Figure I where Islamisation is the foundation. Remarkably, on the $17^{\text {th }}$ December 2014, IIUM has been recognised as a Premier International Islamic Research University by the Islamic Educational, Scientific and Cultural Organisation (ISESCO).

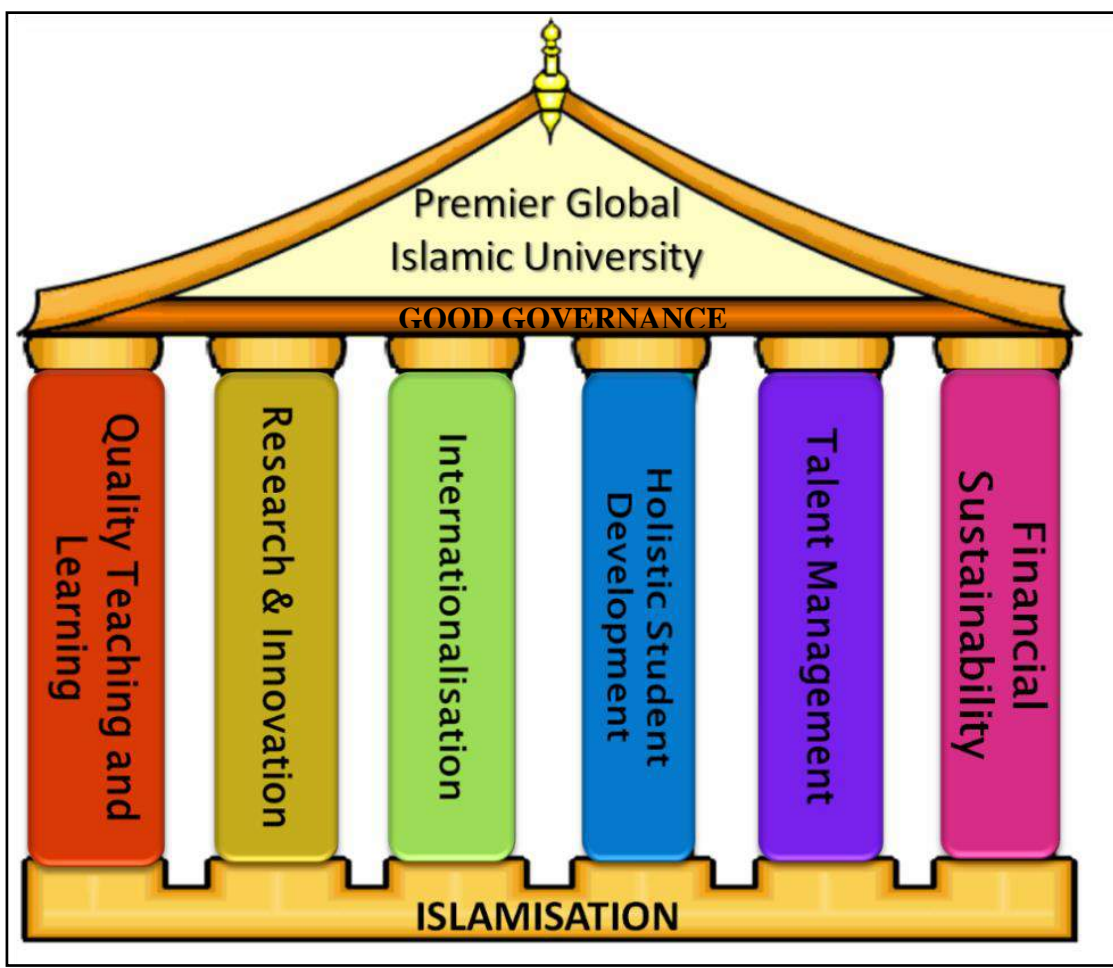

Figure 1: Premier Global Islamic University as follows:

With regard to the Islamisation agenda, IIUM has set key performance indicators

1. Percentage of research, publication and proceedings based on Islamisation of knowledge that are produced in proportion to the total number of staff members.

2. Number of Master and PhD theses completed based on Islamisation of knowledge perspective in proportion to the total number of theses completed. 
Azila Ahmad Sarkawi, Alias Abdullah \& Norimah Md Dali

Islamisation of Town Planning Education: A Review on the Courses Offered by the Department of Urban and

Regional Planning, International Islamic University Malaysia

3. Amount of research and publication funds allocated for Islamisation of knowledge projects in proportion to total amounts of money used for research and publication.

4. Number of nationally and internationally organized seminars, conferences, workshops and related activities based on Islamisation of knowledge perspectives.

5. Level of success in integrating the Islamic values, concepts and perceptions in the curriculum and teaching and learning activities.

6. Number of programmes and course outlines developed based on Islamisation of knowledge input/ perspectives in proportion to total programmes and course outlines.

7. Level of effectiveness of the University Required Courses package and other related subjects in enhancing Islamisation of knowledge in students learning.

8. Level of effectiveness of academic and administrative services in enhancing and achieving the Islamisation of knowledge mission.

9. Number of training and consultation on Islamisation of knowledge provide internally and externally in proportion to the total number of related activities.

The Kulliyyah of Architecture and Environmental Design (KAED) was established on the 1stJune 1996 to fulfill the need for professionals in the built environment. The Kulliyyah offers programmes geared towards integrating Islamic values and the tawhidic educational approach in the built environment profession. This will not only produce graduates who will fulfill the general requirements of the built environment industry, but will also become competent in Research and Development (R\&D) activities. Also, KAED seeks to be a centre of excellence in the built environment that promotes Integration and Islamization of knowledge for the benefit of the Ummah. Hence, KAED is committed to serve the Ummah by producing ethical, competent and versatile graduates and to produce quality research in the field of built environment. This is to be achieved through the provision of innovative leadership and conducive working and learning environment by utilizing the state of the art technology.

KAED offers courses related to architecture, urban and regional planning, landscape architecture, quantity surveying and applied arts and design. This is quite similar to other built environment schools as R. Griffiths (2004, p. 711) mentioned that "the built environment disciplines is a term that has come to be used by many UK universities to refer to a range of practice-oriented subjects concerned with the design, development and management of buildings, spaces and places[...]they are a very heterogeneous collection of fields of study and practice including architecture, town planning, land and property management, building surveying, construction technology, landscape design...”.

KAED is structured under five departments namely Architecture, Quantity Surveying, Urban and Regional Planning, Landscape Architecture and Arts and Design. KAED produces qualified architect, quantity surveyor, town planner, landscape architect and designer annually. But the question is how best is KAED preparing them into the related workforce manifesting their role as professional Muslim architects, quantity surveyors, town planners, landscape architects and designers? There are many factors 
that contribute to the success of this agenda in which one of them is the built environment curriculum.

Table 1: Number of courses, credit, contact hours and accreditation bodies for undergraduate programmes at KAED as of academic session 2013/14

\begin{tabular}{|l|l|l|l|l|}
\hline Programme & $\begin{array}{l}\text { No of } \\
\text { courses }\end{array}$ & $\begin{array}{l}\text { Credit } \\
\text { hour }\end{array}$ & $\begin{array}{l}\text { Contact } \\
\text { hour }\end{array}$ & Accreditation body \\
\hline $\begin{array}{l}\text { B.Sc. (Hons) Architectural } \\
\text { Studies }\end{array}$ & 43 & 120 & 187 & $\begin{array}{l}\text { MQA, JPT, JPA, } \\
\text { LAM Part II }\end{array}$ \\
\hline B. (Hons) Architecture & 17 & 56 & 74 & $\begin{array}{l}\text { MQA, JPT, JPA, } \\
\text { LAM Part II }\end{array}$ \\
\hline $\begin{array}{l}\text { B. (Hons) Urban and Regional } \\
\text { Planning }\end{array}$ & 46 & 146 & 189 & $\begin{array}{l}\text { MQA, JPT, JPA, } \\
\text { Board of Town } \\
\text { Planners. }\end{array}$ \\
\hline $\begin{array}{l}\text { B. (Hons) Landscape } \\
\text { Architecture }\end{array}$ & 52 & 143 & 204 & $\begin{array}{l}\text { MQA, JPT, JPA, } \\
\text { ILAM MAn, JPA, }\end{array}$ \\
\hline $\begin{array}{l}\text { B. (Hons) Quantity Surveying } \\
\text { B. (Hons) Applied Arts and }\end{array}$ & 65 & 142 & 185 & $\begin{array}{l}\text { MQA, JPT, JPA, RISM, } \\
\text { RICS (UK) }\end{array}$ \\
\hline \begin{tabular}{l} 
Design \\
\hline
\end{tabular} & 144 & 206 & MQA, JPT, JPA \\
\hline
\end{tabular}

Source: Khairuddin, 2013

The above number of credit hours for each programme offered is included in the 22 credits for the University required courses as in Table 2.

Table 2: University required courses as of Semester 1, 2014/15

\begin{tabular}{|l|l|}
\hline Revealed Knowledge & \\
AAR 1230 Quran, Sunnah and Built Environment & 3 \\
UNGS 2030 The Islamic Worldview & 3 \\
UNGS 2040 Islam, Knowledge and Civilization & 3 \\
UNGS 2050 Ethics and Fiqh for Everyday Life & 3 \\
\hline Tilawah al-Qur'an I and II & 2 \\
\hline English & 3 \\
\hline Arabic I and II & 0 \\
\hline Bahasa Melayu Kerjaya (Sains dan Teknologi) & 2 \\
\hline Co-curricular & 3 \\
\hline Total & 22 \\
\hline
\end{tabular}

In the pursuit of Islamisation and its key performance indicators set by the University, Khairuddin and Azila (2012) studied issues and challenges facing the Islamisation of the built environment curriculum and level of Islamic inputs in the courses offered. The study revealed that the Islamisation of course content relies on two factors as follow:

i. The academic staff who taught the course - the ability to impart Islamic input in the courses offered varies among KAED staff, Part timer/ Academic trainee and non-Muslim staff, subject to the different exposure on the Islamisation agenda 
Azila Ahmad Sarkawi, Alias Abdullah \& Norimah Md Dali

Islamisation of Town Planning Education: A Review on the Courses Offered by the Department of Urban and

Regional Planning, International Islamic University Malaysia

that they have. Therefore, certain methodology for the recruitment process or during their service with the University need to be devised to ensure the continuity and sustainability of the agenda.

ii. The nature of the courses itself - the technical nature of the courses like computer/graphic application, practical training/degree project, project paper, design thesis and topical studies influence the process of islamisation due to its technicalities where specific methodology is required for its purpose.

The study also revealed few findings on the issues and challenges to Islamisation of knowledge in the built environment, namely:

a) Educational background of the academic staff

b) Technical-nature of the subject

c) Lack of references in the area of Islam and built environment

d) Absence of proper module on Islamisation framework

e) Students' intake from both religious and non-religious secondary school

\section{A Study on the BURP's Course Contents}

The BURP programme contains twenty-two (22) credit hours of the University required courses as listed in Table 2 above, one hundred and eighteen (118) credit hours for planning core courses and six (6) for elective courses. The objectives of this multidisciplinary programme, among others, are:

- To train professionals of a very high standard of competency and knowledge in urban and regional planning

- To install a sense of responsibility and commitment to natural heritage and to have the capacity to monitor their well-being for the future generation through understanding the Tawhidic approach to development planning.

- To cater for the higher level of demands in terms of advanced knowledge and skills in the field of urban and regional planning.

Altogether there are ten intended programme outcomes of the BURP in which Islamisation is one of it other than knowledge, practical skills, social skills and responsibilities, attitudes and professionalism, communication and leadership, problem solving and scientific skills, information management and lifelong learning skills, and managerial and entrepreneurial skills.

The content analysis is deployed in reviewing the programme structure and course contents of the BURP. It appears that the following courses content embodied specific Islamic-related topics; however this paper proposes other areas of Islamic inputs to further enhance the knowledge and for future professional practices as illustrated in Table 3 below. 
Table 3: Courses with specific Islamic-related topics

\begin{tabular}{|c|c|c|}
\hline COURSES & $\begin{array}{c}\text { ISLAMIC-RELATED TOPICS IN } \\
\text { THE COURSE CONTENT }\end{array}$ & $\begin{array}{c}\text { PROPOSED AREA OF ISLAMIC } \\
\text { INPUTS } \\
\end{array}$ \\
\hline 1.Site Planning & $\begin{array}{l}\text {-Principles of Islamic Planning for } \\
\text { town, centres, and public spaces; } \\
\text { Housing; Industry; Tourism/ } \\
\text { recreation; Waste Disposal; } \\
\text { Transportation } \\
\text {-Development policies and ethics in } \\
\text { the site planning project. }\end{array}$ & $\begin{array}{l}\text {-interconnectedness between the term } \\
\text { din (religion) and madinah(city) } \\
\text {-the concept of Islamic built } \\
\text { environment vis.a.vis. Sustainable } \\
\text { development. } \\
\text {-feasibility study in Islam. }\end{array}$ \\
\hline $\begin{array}{l}\text { 2.Introduction to Urban } \\
\text { Design }\end{array}$ & $\begin{array}{l}\text {-Islamic cities and their built heritage } \\
\text {-Islamic Cities; the clash between } \\
\text { tradition and modernity }\end{array}$ & $\begin{array}{l}\text {-urbanisation process during the } \\
\text { Prophet's time. } \\
\text {-planning of the traditional Muslims } \\
\text { city during the early Islam. }\end{array}$ \\
\hline $\begin{array}{l}\text { 3. Introduction to } \\
\text { Housing }\end{array}$ & -Islamic housing principles. & $\begin{array}{l}\text {-functions of home in Islam. } \\
\text {-home as a necessity. } \\
\text {-translating functions of home in } \\
\text { Islam into spatiality. }\end{array}$ \\
\hline $\begin{array}{l}\text { 4. Social and } \\
\text { Community Planning }\end{array}$ & $\begin{array}{l}\text { Doctrine of integral planning and } \\
\text { development: } \\
\text {-Man-God relationship (justice, } \\
\text { ihsan, amanah, respect knowledge) } \\
\text {-Man-Man relationship (privacy, } \\
\text { space distribution, safety, respect, co- } \\
\text { operation, consensus (musyawarah). } \\
\text {-Man-Environment relationship } \\
\text { ( cleanliness, resource planning) }\end{array}$ & $\begin{array}{l}\text {-human beings are collective by } \\
\text { nature, al-Hujurat: } 13 \text {. } \\
\text {-islamic principles governing human } \\
\text { development embodied in fiqh ibadat } \\
\text { (personal), fiqh munakahat (family), } \\
\text { fiqh muamalat (society), and figh } \\
\text { jinayat (crimes and wrongdoings). } \\
\text {-human relationship with the Creator, } \\
\text { his fellow man and the environment. }\end{array}$ \\
\hline $\begin{array}{l}\text { 5.Economics for } \\
\text { Planning }\end{array}$ & $\begin{array}{l}\text {-Income distribution and poverty } \\
\text { analysis. } \\
\text {-Role of Zakat in poverty alleviation. } \\
\text {-Islamic prescription for poverty } \\
\text { alleviation. } \\
\text { Money markets, Mudharabah and } \\
\text { other Shari'ah arrangements. } \\
\text {-Monetary and fiscal policies. } \\
\text {-Consumer Price Index }\end{array}$ & $\begin{array}{l}\text {-economic planning for human } \\
\text { goodness and well-being. } \\
\text {-zakat and waqaf as tools to enhance } \\
\text { socio-economics of the Muslims. } \\
\text {-shari'ah compliance of economic } \\
\text { principles and transactions i.e. fiqh } \\
\text { muamalat in Islam. } \\
\text {-wealth accumulation that bring } \\
\text { people closer to Allah. }\end{array}$ \\
\hline 6. Regional Planning & $\begin{array}{l}\text {-Islamic values related to regional } \\
\text { planning. } \\
\text {-Islamic principles of space } \\
\text { organization. }\end{array}$ & $\begin{array}{l}\text {-fiqh al-siyasah (politics) } \\
\text {-sharing of resources } \\
\text {-consultation, negotiation and } \\
\text { tolerance in mutual dealings }\end{array}$ \\
\hline $\begin{array}{l}\text { 7. Aspects of Land } \\
\text { Valuation }\end{array}$ & $\begin{array}{l}\text {-Understanding land property } \\
\text { concepts. } \\
\text {-Definition of land \& ownership. } \\
\text {-Characteristics \& types of land } \\
\text { property. } \\
\text {-Land interest and property } \\
\text { ownership. }\end{array}$ & $\begin{array}{l}\text {-Allah is the owner of the universe } \\
\text {-Man is the trustee on earth } \\
\text { - sharing of resources for goodness } \\
\text {-right of use and enjoyment of } \\
\text { property in Islam }\end{array}$ \\
\hline 8. Planning Theory & $\begin{array}{l}\text {-Theory of Islamic planning } \\
\text {-Built environment concept in Islam } \\
\text {-Environmental design and planning } \\
\text { of Islamic perspective } \\
\text {-Ethical challenge of Islamic built } \\
\text { environment }\end{array}$ & $\begin{array}{l}\text {-human beings are khalifah on earth. } \\
\text {-Muslims are religiously bound to } \\
\text { plan, design, or construct the earth } \\
\text { according to its nature created by } \\
\text { Allah. } \\
\text {-islamic town planning is an ibadah. }\end{array}$ \\
\hline $\begin{array}{l}\text { 9. Comparative } \\
\text { Planning Systems }\end{array}$ & $\begin{array}{l}\text {-There will be a study visit to either } \\
\text { one of the following countries: }\end{array}$ & $\begin{array}{l}\text {-lessons learnt from other countries in } \\
\text { any of their planning systems that } \\
\text { comply with Islamic teachings. }\end{array}$ \\
\hline
\end{tabular}


Azila Ahmad Sarkawi, Alias Abdullah \& Norimah Md Dali

Islamisation of Town Planning Education: A Review on the Courses Offered by the Department of Urban and Regional Planning, International Islamic University Malaysia

\begin{tabular}{|c|c|c|}
\hline & $\begin{array}{l}\text { Saudi Arabia, Egypt or Turkey, } \\
\text { Singapore, Indonesia, Thailand, } \\
\text { Australia }\end{array}$ & \\
\hline $\begin{array}{l}\text { 10. Elements of } \\
\text { Infrastructure }\end{array}$ & $\begin{array}{l}\text {-Planning public religious amenities - } \\
\text { mosque, surau, madrasah, musollah, } \\
\text { concept of prayer in Islam in relation } \\
\text { to amenity planning, planning } \\
\text { guidelines and basic design } \\
\text { requirements }\end{array}$ & $\begin{array}{l}\text {-the concept of inviting good and } \\
\text { forbidding bad in Islam. } \\
\text {-preservation of faith according to the } \\
\text { maqasid al-shari'ah. } \\
\text {-translation of the Islamic principles } \\
\text { into the physical planning }\end{array}$ \\
\hline $\begin{array}{l}\text { 11. Principles of Urban } \\
\text { and Regional Planning } \\
1\end{array}$ & $\begin{array}{l}\text {-Islamic perspective on planning } \\
\text { system } \\
\text {-Distribution of scarce resources } \\
\text {-Sustainability } \\
\text {-Total planning doctrine }\end{array}$ & $\begin{array}{l}\text {-human beings are khalifah on earth. } \\
\text {-Muslims are religiously bound to } \\
\text { plan, design, or construct the earth } \\
\text { according to its nature created by } \\
\text { Allah. } \\
\text {-islamic town planning is an ibadah. }\end{array}$ \\
\hline 12. Islamic Urbanism & $\begin{array}{l}\text {-the civilisation and urbanisation } \\
\text { processes in the Islamic cities } \\
\text {-Islamic urban settlements, urban } \\
\text { forms, building process, planning } \\
\text { principles, space and building } \\
\text { functions, housing, town centre, } \\
\text { mosque, road networks and } \\
\text { architectural elements. } \\
\text {-Islamic law and neighbourhood } \\
\text { building guidelines, community } \\
\text { development, environmental } \\
\text { conservation. } \\
\text {-History of Islamic architecture and } \\
\text { urbanism in accordance with the } \\
\text { materials, methods of construction, } \\
\text { social organisation, and cultural } \\
\text { attitudes in different periods of } \\
\text { history. }\end{array}$ & $\begin{array}{l}\text {-explained with a tafsir of relevant } \\
\text { Quranic verses and hadith. } \\
\text {-illustrated and supported with the } \\
\text { practices of the Companions and } \\
\text { Muslims scholars. } \\
\text {-application to contemporary planning }\end{array}$ \\
\hline
\end{tabular}

It is therefore advocated that lecturers incorporate other more specific areas of Islamic-related topics into the conventional course content. For the purpose of enhancement and strengthening the application of the Islamic principles in contemporary body of knowledge, besides the compatible areas of Islamic inputs proposed, teaching collaboration with lecturers from the Islamic studies kuliyyah should be instituted. The purpose of the collaboration is to expose the students with the tafsir of the Quranic injunctions and Prophetic Reports related to the topic together with the practices of the Companions and Muslim scholars in early Islam.

Nevertheless, these Islamic-related topics inserted in the planning course outline were doubled illuminated with the University required courses as in Table 4. 
Table 4: University Required Courses

\begin{tabular}{|c|c|}
\hline \multicolumn{2}{|r|}{ UNIVERSITY REQUIRED COURSES - course synopsis } \\
\hline $\begin{array}{l}\text { 1.Quran, Sunnah and } \\
\text { Built Environment }\end{array}$ & $\begin{array}{l}\text { Acquainting students with the facts on philosophies and principles of the built } \\
\text { environment that had been laid down in the Holy Qur'an and the Practices of } \\
\text { the Prophet Muhammad. Appropriate verses and text from the Holy Qur'an } \\
\text { and Sunnah are referred in the context of the built environment. The origins } \\
\text { and first manifestations of the identity of the built environment distinctly came } \\
\text { into sight during the time of the Prophet and the first generation of Muslims } \\
\text { are scrutinised. }\end{array}$ \\
\hline $\begin{array}{l}\text { 2.The Islamic } \\
\text { Worldview }\end{array}$ & $\begin{array}{l}\text { Focusing on the meanings, characteristics and kinds of worldviews including } \\
\text { some selective contemporary ideologies, such as materialism, secularism and } \\
\text { post modernism. It presents an overview of Islam and its main characteristics, } \\
\text { also describes the elements of Islamic worldview and reviews some of the } \\
\text { contemporary challenges facing man and society. }\end{array}$ \\
\hline $\begin{array}{l}\text { 3.Islam, Knowledge and } \\
\text { Civilization }\end{array}$ & $\begin{array}{l}\text { Dealing with the basic issues that lead to a good understanding of the theory of } \\
\text { knowledge and civilization from the Islamic and the non-Islamic perspectives. } \\
\text { It describes the contribution of Muslim scholars and scientists in different } \\
\text { fields of knowledge and science throughout the history of the Muslim } \\
\text { civilization, also reviews some contemporary challenges facing the Muslim } \\
\text { Ummah and the possible solutions to overcome them with reference to the } \\
\text { concept of Islam Hadhari. }\end{array}$ \\
\hline $\begin{array}{l}\text { 4.Ethics and Fiqh for } \\
\text { Everyday Life }\end{array}$ & $\begin{array}{l}\text { Consists of two parts: a) Islamic ethics, b) fiqhfor everyday life. The first part } \\
\text { focuses on core Islamic ethical concepts, family ethics, and Islamic ethics as } \\
\text { applied in different professions, inter-personal ethics, and ethnic relations. The } \\
\text { second part deals with general view of Islamic fiqhand its schools, maqasid al- } \\
\text { shari 'ah, major bio-ethical and financial issues. }\end{array}$ \\
\hline $\begin{array}{l}\text { 5.Tilawah al-Qur'an I } \\
\text { and II }\end{array}$ & $\begin{array}{l}\text { Familiarise the students with the rules of reading the Qur'an (tajwid) and } \\
\text { memorisation skills. }\end{array}$ \\
\hline
\end{tabular}

Meanwhile, the other planning core course which is silent on the Islamic-related topics is worth mentioning here in the pursuit of Islamisation. Following the 22 modes devised by the Centre for Islamisation (CENTRIS), IIUM (Appendix 1) these courses might fall under any of the modes outlined.

Reviewing the content of the course outlines where the Islamic-related topic is not mentioned specifically suggest that the Islamic inputs could be in term of values and ethics. With the insertion of the Islamic-based values such as knowledge, systematic, critical and analytical thinking, teamwork, networking, da'wah, accountability, transparency, honesty, punctuality, justified decision making, leadership, talented, ikhlas, efficient, proactive, respect, trust, preservation of maqasid al-shari'ah, Islamic environmental ethics, self-conscious and etc. under the notion of inviting good and forbidding bad, the percentage of Islamic input in the courses will increase tremendously. These Islamic attributes when doubled up with the team-teaching lecturing mode will result in a more robust Islamisation process of the town planning education.

Based on the credit hours calculation, 34\% of planning courses offered by KAED embodied specific Islamic related topic, while the remaining $66 \%$ is silent. Therefore this study identifies proportion of Islamic related topic and non-specific Islamic related topic appeared in planning curriculum shown in Table 6.

Stemming from the issue of the educational background of majority of the academic staffs in the built environment who are from non-religious educational background, the paper proposes team-teaching with lecturers from the religious studies 
Azila Ahmad Sarkawi, Alias Abdullah \& Norimah Md Dali

Islamisation of Town Planning Education: A Review on the Courses Offered by the Department of Urban and

Regional Planning, International Islamic University Malaysia

department. Prior to the teaching commencement, there must be a discussion between both lecturers from the department of the planning and the Islamic studies so that the content to be delivered will be more compatible and meeting the expectation. This teamteaching strategy will integrate the Islamic insights into the contemporary planning body of knowledge directly that will flourish the Islamisation agenda. At the end of the programme, students are expected to grasp the following ideas from the planning education:

i. Town planner as a khalifah

ii. Town planner's work as an ibadah (Allah worshipping)

iii. Al-Qur'an and al-Sunnah as a source of planning decision-making tool via ijtihad

iv. Interconnectedness between din (religion) and madinah (city) as a planning basis

v. Belief in reward and punishment in the Hereafter for every planning undertaking.

More importantly, the planning curriculum must be able to meet the ultimate aim of the shari'ah that is the preservation of the following:

i. Faith - curriculum that would enable students to embrace the presence of Allah in every human undertakings, acts or omissions, directed by His revelation through the Al-Qur'an and Al-Sunnah.

ii. Self - curriculum that would enable students to embrace the greatness of Allah in creating human beings thus directed people to perform their role as khalifah in acts or omissions towards fellow men and the environment.

iii. Intellect - curriculum that would enable students to acquire the intellectual skills and knowledge to understand the subject matter of any kind or branch of contemporary knowledge and able to appraise what is right and what is wrong according to one's Faith.

iv. Lineage - curriculum that would enable students to appreciate the collective nature of human beings thus giving rise to the practice of Islamic values and etiquette in society, inviting good and forbidding bad.

v. Property - curriculum that would enable students to acquire skill and knowledge to ensure that physical development are being developed with value for money, sustainable and lasting with minimum maintenance.

Indeed the preservation of these five elements of the Maqasid al-Shari'ah is in line with the spirit of the Malaysian Shari'ah Index launched on February 10, 2015 by the Prime Minister. Infrastructure and the environment forms one of the sectors under scrutiny by the government apart from other seven sectors that have been emphasized in the Malaysian Shari'ah Index. Thus, it is timely for the town planning education in the tertiary learning institution pioneered by KAED, IIUM to gear up towards inculcating the Islamic inputs in the planning curriculum. 
Table 5: Planning Core Courses without specific Islamic-related topic mentioned NON-SPECIFIC ISLAMIC-RELATED TOPIC MENTIONED IN THE COURSE CONTENT

\begin{tabular}{|c|c|}
\hline $\begin{array}{l}\text { 1.Project Management } \\
\text { For Built } \\
\text { Environment }\end{array}$ & $\begin{array}{l}\text { Various aspect of project management starting from project initiation up to } \\
\text { project completion in ensuring the project objectives of time, cost and quality are } \\
\text { achieved. The various technique of project planning, organizing and controlling } \\
\text { be taught including the use of specialised computer applications. The importance } \\
\text { of human aspects of project management will also be highlighted. }\end{array}$ \\
\hline $\begin{array}{l}\text { 2.Professional } \\
\text { Planning Practice }\end{array}$ & $\begin{array}{l}\text { A detailed understanding of the professional planning practice in Malaysia with } \\
\text { some references on planning practice in the United Kingdom. Among other } \\
\text { things, students will be exposed to the nature and scope of work of town planners } \\
\text { in the public and private sectors, its relationship with other professions in the built } \\
\text { environment, professional services, procedures in plan-making process and the } \\
\text { roles of town planners in developing the Ummah. }\end{array}$ \\
\hline $\begin{array}{l}\text { 3.Public } \\
\text { Administration And } \\
\text { Finance }\end{array}$ & $\begin{array}{l}\text { Administrative and financial aspects of urban and regional planning as well as } \\
\text { scope of planning, spatial levels of planning, organisation management, } \\
\text { machinery of planning administration, relationship between Federal, State and } \\
\text { Local Government will be taught to students. }\end{array}$ \\
\hline $\begin{array}{l}\text { 4.Project Impact } \\
\text { Assessment }\end{array}$ & $\begin{array}{l}\text { The environmental issues and its various types of impacts to the surrounding. As } \\
\text { such, it is important for planning students to inculcate this knowledge as planning } \\
\text { deals a lot with development of natural resources. }\end{array}$ \\
\hline $\begin{array}{l}\text { 5. Planning Law And } \\
\text { Procedure }\end{array}$ & $\begin{array}{l}\text { An understanding on laws relating to town and country planning. Laws relating } \\
\text { to town and country planning branches including environment, socio-economic, } \\
\text { land use, traffic and etc. Each of these planning subjects is regulated by law for } \\
\text { their operating process to ensure its efficiency and effectiveness. Therefore, this } \\
\text { course covers those related statutory provisions embodied in Town and Country } \\
\text { Planning Act 1976, Local Government Act 1976, Environmental Quality Act } \\
\text { 1974, National Land Code 1965, Street, Drainage and Building Act 1974, } \\
\text { Uniform Building By-Laws } 1984 \text { etc. Students will be involved with field } \\
\text { studies, attending Appeal Board sessions or hearings on planning disputes. }\end{array}$ \\
\hline $\begin{array}{l}\text { 6. Planning } \\
\text { Techniques }\end{array}$ & $\begin{array}{l}\text { Various techniques/ tools which are applied in different phases of the planning } \\
\text { activities. As such the course contains the following topics: definition of planning } \\
\text { and different conceptions of planning; planning process and techniques; strategic } \\
\text { planning and SWOT analysis; planning information - types \& sources; } \\
\text { forecasting techniques; models in planning; population analysis and projections; } \\
\text { land use analysis; economic base analysis and employment forecasting; plan } \\
\text { evaluation techniques; plan implementation and communication techniques. }\end{array}$ \\
\hline 7.Planning Theory & $\begin{array}{l}\text { Overviews of literature on planning theories and philosophies; explanations of a } \\
\text { conceptual framework for planning thought, positive planning, traditional } \\
\text { planning, organizations, decision making, the politics of rational planning, } \\
\text { political and social contexts of planning. It examines planning as a } \\
\text { communicative process from formulations of complex issues to proposed actions. } \\
\text { The role of debate, arguments, objection, participation, documents and basic } \\
\text { forms of planning processes are presented. It also attempts to survey the broad } \\
\text { areas of how planning is practiced and the problems faced by planners. Attention } \\
\text { is also given to the concepts such as mode of planning, style of planning, } \\
\text { implementation structures and organizational processes that act as heuristic } \\
\text { approaches in the planning process. }\end{array}$ \\
\hline $\begin{array}{l}\text { 8. Principles Of Urban } \\
\text { And Regional } \\
\text { Planning } 2\end{array}$ & $\begin{array}{l}\text { Continuation of the Principles of Urban and Regional Planning } 1 . \\
\text { Factors that influenced planning and decision making processes including } \\
\text { government intervention, scarcity of land, pursuit of economic growth, society } \\
\text { aspirations and needs, and pursuit of sustainable development objectives. }\end{array}$ \\
\hline 9.Geomatic & $\begin{array}{l}\text { Provides an overview of }(a) \text { Land Surveying - Fundamentals of land surveying } \\
\text { concepts, technology and applications; }(b) \text { Remote Sensing - Fundamentals of } \\
\text { satellite and aerial remote sensing concepts, technology, and applications. The } \\
\text { fieldwork and laboratory sessions consist of hands-on exercises that are intended } \\
\text { to broaden student understanding of Geomatics. }\end{array}$ \\
\hline
\end{tabular}


Azila Ahmad Sarkawi, Alias Abdullah \& Norimah Md Dali

Islamisation of Town Planning Education: A Review on the Courses Offered by the Department of Urban and Regional Planning, International Islamic University Malaysia

\begin{tabular}{|c|c|}
\hline $\begin{array}{l}\text { 10.Planning And } \\
\text { Decision Support } \\
\text { System }\end{array}$ & $\begin{array}{l}\text { Understand how planning decisions have been made to ensure resources can be } \\
\text { fully utilised and sustained } \\
\text { To provide planning scenarios, to choose some options in planning, to analyse } \\
\text { consequences and to provide trade off, to project future needs and land allocation, } \\
\text { and to monitor the implementation of plans. }\end{array}$ \\
\hline $\begin{array}{l}\text { 11. CAD \&Multimedia } \\
\text { For Planning }\end{array}$ & $\begin{array}{l}\text { An exploration of the variety of CAD and graphic tools available for modelling, } \\
\text { understanding and presenting design proposals. Applications explored include } \\
2 \mathrm{D} \text { and } 3 \mathrm{D} \text {, simple visualisation, image editing and composition and the } \\
\text { crossovers possible between these various techniques. Conceptual modelling } \\
\text { techniques for design process and their relevance to the design studio will be } \\
\text { discussed. }\end{array}$ \\
\hline $\begin{array}{l}\text { 12.GIS Application } \\
\text { For Built Environment }\end{array}$ & $\begin{array}{l}\text { Topics covered in this subject are the history of GIS, components of GIS, } \\
\text { hardware and software requirement, raster and vector GIS, projections, data } \\
\text { structure and concepts, data acquisition, making spatial data usable, getting } \\
\text { attribute data into GIS, database management, data manipulation and analysis, } \\
\text { metadata, product generation and customization. }\end{array}$ \\
\hline $\begin{array}{l}\text { 13. Urban Traffic } \\
\text { System }\end{array}$ & $\begin{array}{l}\text { Urban traffic system is a part of transportation study. It is important to urban and } \\
\text { regional planning field in order to provide accessibility by road network planning. } \\
\text { This course offers understanding on various topics such as road traffic trends in } \\
\text { urban areas, the impact of natural condition, road and vehicular characteristics, } \\
\text { traffic survey, highway capacity, road and intersection design, traffic signal } \\
\text { design and operation, parking study, and traffic management. }\end{array}$ \\
\hline $\begin{array}{l}\text { 14. Transportation } \\
\text { Planning }\end{array}$ & $\begin{array}{l}\text { Transportation is concerned with the movement of people and goods. The study } \\
\text { of movement between places (land uses) for various purposes by using different } \\
\text { types of transportation mode is considered as one of the main aspects in } \\
\text { transportation planning. The course covers several topics related to the present } \\
\text { transportation problems, service operations, urban travel behavior, transportation } \\
\text { planning model and transportation system management. The course is also } \\
\text { designed to give students a thorough grounding in understanding transportation } \\
\text { planning system and methodology. }\end{array}$ \\
\hline $\begin{array}{l}\text { 15.Research Method } \\
\text { For Built Environment }\end{array}$ & $\begin{array}{l}\text { Approaches to research methodology which can later be used in writing their } \\
\text { theses. Focusing on the understanding of the nature and types of data, collection } \\
\text { of data, sampling technique, methods of data analysis and report writing. }\end{array}$ \\
\hline 16. Project Paper & $\begin{array}{l}\text { Develop students' ability to identify planning problems and provide solutions to } \\
\text { the problems. Formulate problems for research, literature review, field and library } \\
\text { research, elements of sampling, data analysis, data presentation and } \\
\text { interpretation, writing reports. Skill acquired by student is research and inquiry } \\
\text { through identification of problems and finding solutions to identified problems. }\end{array}$ \\
\hline 17.Practical Training & $\begin{array}{l}\text { The objective is to produce intellectual and competent students through the real } \\
\text { practices of town and country planning. Practical training will be conducted at } \\
\text { various government departments, agencies and private firms that have been } \\
\text { approved by the Department. At the end of the practical training session each } \\
\text { students is required to submit a written report detailing his task and experiences } \\
\text { during the practical training period. }\end{array}$ \\
\hline 18.Planning Studio 1 & $\begin{array}{l}\text { Understanding of basic planning technical skills. It covers topics on planning } \\
\text { issues, problems, standards and guidelines, types of plans and scales, } \\
\text { cartographic presentation, layout evaluation, site investigation, and inventory and } \\
\text { analysis. Studio projects will incorporate regulations, standard and planning } \\
\text { guidelines knowledge for planning various types of land use. Islamic working } \\
\text { ethics such as unity, team work and respecting the knowledge will be introduced } \\
\text { in the studio projects as a preparation for working life. }\end{array}$ \\
\hline 19.Planning Studio 2 & $\begin{array}{l}\text { Related to site planning, layout design and master plan preparation. Students are } \\
\text { guided to conduct literature reviews related to mixed development. Inception and } \\
\text { Technical reports will be prepared to support the layout plan making and its } \\
\text { master plan for a mixed development. }\end{array}$ \\
\hline
\end{tabular}




\begin{tabular}{|l|l|}
\hline 20.Planning Studio 3 & $\begin{array}{l}\text { The preparation of a statutory development plan called Special Area Plan } \\
\text { (RancanganKawasanKhas). Reference is made of the provisions under Town and } \\
\text { Country Planning Act 1976 (Act 172). }\end{array}$ \\
\hline 21.Planning Studio 4 & $\begin{array}{l}\text { The preparation of a statutory district local plan under the Act 172. The course } \\
\text { will cover the investigation of housing, land use, transportation, environment and } \\
\text { others. Modelling and forecasting techniques will eventually be used to analyse } \\
\text { the existing condition and then wisely predict the future condition. Students are } \\
\text { required to produce a draft District Local Plan for the study area, which will } \\
\text { consist of major projections of what the future land use would be and the } \\
\text { accompanying policies and detail proposals which take into consideration the } \\
\text { wider contexts of neighbouring developments and statutory development plans } \\
\text { on the higher tier of the hierarchy of development plan. }\end{array}$ \\
\hline 22.Planning Studio 5 & $\begin{array}{l}\text { The preparation of a statutory state structure plan at a strategic level under the } \\
\text { Act 172. The course will cover the investigation of housing, land use, } \\
\text { transportation, environment and others. Modelling and forecasting techniques } \\
\text { will eventually be used to analyse the existing condition and then wisely predict } \\
\text { the future condition. Students will be required to produce a draft State Structure } \\
\text { Plan for the project area which will consist of major projections of what the future } \\
\text { land use would be and the accompanying policies and general proposals which } \\
\text { take into consideration the wider contexts of regional developments. }\end{array}$ \\
\hline 23.Planning Studio 6 & $\begin{array}{l}\text { The preparation of Development Proposal Report (DPR). Students are required } \\
\text { to conduct detailed literature reviews related to a large scale and futuristic type } \\
\text { of development. Feasibility and Market Study report and Technical report will be } \\
\text { prepared as well to support the preparation of DPR. }\end{array}$ \\
\hline
\end{tabular}

Table 6: Proportion of Islamic Input in the Planning Courses

\begin{tabular}{|c|c|c|c|}
\hline Course content & $\begin{array}{c}\text { Planning core courses } \\
\text { (No. Of Credit hours) }\end{array}$ & $\begin{array}{c}\text { University required } \\
\text { courses } \\
\text { (No. Of Credit hours) }\end{array}$ & $\begin{array}{c}\text { Total } \\
\text { (Credit Hours) }\end{array}$ \\
\hline Specific Islamic-related topic & 34 & 14 & $48(34 \%)$ \\
\hline $\begin{array}{l}\text { Non-specific Islamic-related } \\
\text { topic }\end{array}$ & 84 & 08 & $92(66 \%)$ \\
\hline Total (Credit hours) & 118 & 22 & $140^{*}$ \\
\hline
\end{tabular}

*Six credit hours of elective courses are excluded from the study

\section{CONCLUSION}

While efforts in Islamisation in the town planning curriculum have been instituted and practiced in KAED since its inception in 1996, there are still room for further improvements and enhancements. Now, after almost two decades, this study evaluates and reviews the past and present course outlines and see where the areas that need better Islamic contents for future courses are. This paper offers two concrete proposals. One is the detailed subject contents and the other is the team-teaching strategy between lecturers of the Town planning department and the Islamic Studies department of IIUM. This twoprong approach is thought to be an effective mechanism for IIUM in its long term Islamisation of knowledge and be a leader in this mission, not only for Malaysian Universities but for the world at large. 
Azila Ahmad Sarkawi, Alias Abdullah \& Norimah Md Dali

Islamisation of Town Planning Education: A Review on the Courses Offered by the Department of Urban and

Regional Planning, International Islamic University Malaysia

\section{ACKNOWLEDGEMENTS}

The research for this paper was financially supported by the MyRa Incentive Research Grant Scheme (MIRGS) 2013 (Project ID: MIRGS 13-02-001-0005) Ministry of Education Malaysia. We would like to thank the Government of Malaysia particularly the Ministry of Education and International Islamic University Malaysia in accomplishing this research.

\section{REFERENCES}

Amaratunga, Dilanthi et al. (2005). Research Knowledge Transfer into Teaching in the Built Environment. 587-601.

Azila Ahmad Sarkawi and Khairuddin Abdul Rashid. (2012).Islamicisation of Human Knowledge in the Built Environment: Issues \& Challenges. Paper presented at First International Conference on Islamic Built Environment: Towards an Understanding of the Islamic Built Environment organized by IIUM and Bandung Islamic University (UNISBA), Indonesia.

Azila Ahmad Sarkawi \& Khairuddin Abdul Rashid. (2012). Islamicisation of Human Knowledge in the Built Environment Education: A Survey on the Courses Offered by KAED, IIUM. In; First International Conference on Islamic Built Environment "Towards an Understanding of the Islamic Built Environment". 28th \& 29th March 2012. Bandung Islamic University (UNISBA)

Abdul Kabir Hussain Solihu (2012). The Islamic Worldview, Ethics and Civilization. IIUM Press.

Banitalebi, M., Yusoff, K., Roslan, M., \&Nor, M. (2012). The Impact of Islamic Civilization and Culture in Europe During the Crusades, 2(3), 182-187.

Bernama (2015). Prime Minister, 10 February 2015.

Bartuska, T. (n.d.) Values, Architecture and Context: The Emergence of an Ecological Approach to Architecture and the Built Environment. ACSA Annual Conference Proceedings.

Choudhury, Masudul Alam, and Mohammad Akram Nadwi (1992). "A Critical Examination of the Concept of Islamization of Article Information". 60-106.

Chynoweth, Paul, and Paul Chynoweth. (2009). "The Built Environment Interdiscipline Research and Teaching.".301-309.

CENTRIS (2013). IIUM Policies and Guidelines on Islamisation.

Department of Urban and Regional Planning (2013) Programme Structure of Urban and Regional Planning.

Freestone and Wood (2006). Exploring Strategies for Linking Research and Teaching. Journal for Education and Built Environment. Vol 1.94-111.

Griffiths (2004). Knowledge production and the research-teaching nexus: the case of built environment disciplines. Carfax Publishing. 709-726.

Khairuddin Abdul Rashid (2013). A Review of KAED's Performance in The Implementation of The Islamisation of Acquired Human Knowledge (IoHK) in Architecture and The Built Environment. 1-32.

Kania, Romly and Zarman (2011). Value Education in The Perspective of Western and Islamic Knowledge. Paper presented at International on Islamic Education Ibn Khaldun University Bogor. 
Keeble (1969). Principles and Practice of Town and Country Planning.

Louay Safi (1996). The Foundation of Knowledge. International Islamic University Malaysia and International Institute of Islamic Thought.

Mohamed Aslam Haneef (2009). A Critical Survey of Islamization of Knowledge. IIUM Press.

Munawar Haque, Kabuye Uthman Sulaiman, Bachir Soualhi and Syamsuddin ARIF (2010). Islam Knowledge and Civilization. IIUM Press.

Muhammad Mumtaz Ali (2014). Issues in Islamization of Human Knowledge. IIUM Press.

Mohannak, Kavoos (2011). Diversity of Knowledge Management: A Cultural Approach. Economic Research Center.1-34.

Appendix 1

1. Accepting, appreciating, acknowledging, affirming, promoting, supporting or perpetuating useful secular-based conventional knowledge, without making serious efforts to develop, integrate or incorporate Islamic worldview into the subject matter.

2. Undertaking, doing or involving in normal, ordinary quality research, publication, consultancy, public service or social work, in harmony with the worldview of Islam.

3. Enjoining, encouraging or adopting that which is considered useful in secular-based conventional systems, after undertaking serious and objective analysis of its compatibility with the Islamic worldview/principles.

4. Improvising or adapting the acceptable or compatible secular-based conventional systems without undermining the principles of Islam (especially when the Islamic solution is not present at the moment in contemporary Muslim societies to serve as better alternatives).

5. Describing, explaining or analyzing in a scholarly and objective manner any secularbased conventional systems without showing in what ways are the Islamic different or more desirable.

6. Undertaking, doing or involving in useful, or good quality research, publication, consultancy, public service or social work, in harmony with the worldview of Islam.

7. Correcting, amending, removing or deleting some aspects of secular-based conventional knowledge which have been evaluated from Islamic worldviews and found to be unacceptable as they are.

8. Comparing or contrasting the secular-based conventional aspects with the Islamicbased counterparts, with the purpose of demonstrating how the Islamic alternatives are better and more desirable.

9. Presenting, promoting or articulating Islamic perspectives on aspects of human knowledge in various fields which are constructed or based upon the worldview of Islam.

10. Serious critiquing and/or critical assessment or evaluation of aspects of secular-based conventional human knowledge - insofar they are not in harmony with the worldview of Islam.

11. Integrating, incorporating or injecting — where necessary-Islamic worldview into the acceptable aspects of secular-based conventional human knowledge for a better and more correct understanding of the holistic nature of truths of human realities. 
Azila Ahmad Sarkawi, Alias Abdullah \& Norimah Md Dali

Islamisation of Town Planning Education: A Review on the Courses Offered by the Department of Urban and

Regional Planning, International Islamic University Malaysia

12. Refuting, rejecting, prohibiting, discouraging, objecting, countering, repelling or deconstructing all aspects of human knowledge which are opposed to Islamic worldviews/principles.

13. Defending, protecting, supporting Islamic perspectives vis-à-vis the unjust criticisms or attempts to undermine or discredit Islam.

14. Reorienting aspects of acquired human knowledge after carefully examining and critically identifying the unacceptable or objection able aspects from non-Islamic religious beliefs.

15. Synthesizing or harmonizing or enriching the positive and acceptable aspects of secular-based conventional knowledge with the relevant Islamic principles.

16. Undertaking, doing or involving in very useful or high quality standard research with the worldviews, principles, ethics and values of Islam.

17. Discovering, revitalizing, operationalizing, or reinterpreting in a positive way the useful knowledge from the rich Islamic intellectual and civilizational legacy and making them relevant and applicable to the contemporary period as problems solving tools.

18. Producing important and highly desirable new inventions in the form of academic or scientific tools which may have high economic potential thus manifesting the creativity and innovativeness of Muslims.

19. Reconstructing or providing significant alternatives to major or dominant secularbased conventional thoughts based on the Islamic worldviews.

20. Constructing new and highly significant human knowledge based on the worldview of Islam.

21. Undertaking and excelling in outstanding or extremely useful or very high quality standard, research, publication, consultancy, etc. with the worldview of Islam.

22. Re-examining, reassessing, re-evaluating, reintegrating, restoring or reviving of selected classical Islamic thought and works with the aim of highlighting their contemporary relevance, usefulness or otherwise. 